ROCZNIKI TEOLOGICZNE

Tom LXVI, zeszyt $4-2019$

DOI: http://dx.doi.org/10.18290/rt.2019.66.4-3

\title{
MATEUSZ LECHWAR
}

\section{ODDZIAŁ KOSYNIERÓW Z BIEŹDZIEDZY - POWSTANIE I DZIAŁALNOŚĆ}

\author{
THE KOSYNIERZY UNIT FROM BIEŹDZIEDZA \\ - BEGINNING AND ACTIVITY
}

\begin{abstract}
A b s t r a c t. The Kościuszko Uprising of 1794 was extremely important in the history of Poland. The memory of it, as well as Tadeusz Kościuszko, poured into the hearts of the Poles the hope of regaining independence.

The increase of national consciousness among the peasantry in Galicia combined with the social work (including patriotic one) of priests among them resulted in the creation of many formations aimed at maintaining the spirit of patriotism.

Kosynierzy unit in Bieździedza perfectly fits into this trend combining the ideas of the Young Poland with the incentives flowing from Bishop Józef Sebastian Pelczar.

Many difficulties are caused by the exact reconstruction of the history of the discussed unit, because of very few written sources. The memories of people as well as the tradition passed on are invaluable in this case.

This article presents the history of the beginning of the Kosynierzy unit and its fate. The work also describes uniforms and armaments and indicates what role those who belong to him play today.
\end{abstract}

Key words: Bieździedza; Kosynierzy; Kościuszko Uprising; unit.

\section{INSUREKCJA KOŚCIUSZKOWSKA}

Powstanie narodowe, rozpoczęte 24 marca 1794 r. przeciw Rosji, a następnie skierowane również przeciwko Prusom, miało niebywały wpływ na kształtowanie

Mgr lic. Mateusz LechwaR - doktorant Instytutu Historii Kościoła i Patrologii KUL; adres do korespondencji: Al. Racławickie 14, 20-950 Lublin; e-mail: mat-lech@wp.pl; ORCID: 0000-00017364-2061. 
się mentalności Polaków. Pamięć o nim, pomimo klęski, przetrwała wieki i znalazła odbicie w różnych formach działalności patriotycznej narodu, który począwszy od pierwszego rozbioru w $1772 \mathrm{r}$. nie zgadzał się z polityką państw zaborczych.

Samo powstanie z marca 1794 r., którego Najwyższym Naczelnikiem został Tadeusz Kościuszko, spowodowane było m.in. II rozbiorem Polski i rządami zwolenników konfederacji w Targowicy. Przygotowywane było przez koła patriotyczne w kraju i na emigracji, przy udziale m.in. Hugo Kołłątaja czy Ignacego Potockiego, którzy kierowali rozgałęzionym spiskiem i intensywną mobilizacją mającą zaskoczyć władze cesarskie ${ }^{1}$. Na arenie międzynarodowej kierownictwo powstania bezskutecznie starało się uzyskać pomoc rewolucyjnej Francji². Wybuch powstania przyspieszyła zarządzona przez Osipa Igelströma - dowódcę wojsk rosyjskich - redukcja wojska polskiego o połowę i przymusowy werbunek zredukowanych żołnierzy do armii rosyjskiej i pruskiej, jak również aresztowania wśród warszawskich sprzysiężonych. W połowie marca Antoni Madaliński odmówił redukcji wojska i na czele 1200 żołnierzy kawalerii narodowej wyruszył w kierunku Krakowa, gdzie 24 marca ogłoszono akt powstania ${ }^{3}$.

Podjęte działania nie byłyby w ogóle możliwe bez zaangażowania mieszczan i chłopów, których werbowano do wojska. Zasoby broni były mocno ograniczone, a narodowe źródła nie były w stanie zaopatrzyć wszystkich żołnierzy w niezbędną broń palną czy działa artyleryjskie. Zrodziła się potrzeba zorganizowania innego rodzaju uzbrojenia, którym miały stać się piki i kosy. Niedoświadczenie żołnierzy z werbunku nie przeszkodziło jednak, by utworzone oddziały kosynierów i pikinierów wzięły udział w bitwie pod Racławicami ${ }^{4}$. 4 kwietnia stoczono z wojskami rosyjskimi bój, w którym zwycięstwo możliwe było właśnie dzięki walecznym oddziałom uzbrojonym $\mathrm{w}$ broń drzewcową. Ta zwycięska bitwa przyspieszyła wybuch powstania na różnych terenach Polski. Na przełomie marca i kwietnia do powstania przyłączyły się oddziały polskie z Lubelszczyzny i zachodniego Wołynia. Wojsko polskie oraz mieszkańcy Warszawy 17 kwietnia rozbili silny garnizon rosyjski i wyzwolili stolicę ${ }^{5}$. Już 22 kwietnia wybuchło powstanie w Wilnie, kierowane przez Jakuba Jasińskiego ${ }^{6}$.

\footnotetext{
${ }^{1}$ W.J. WysOcKI, Wtadze powstańcze w 1974 r., w: Insurekcja Kościuszkowska w dziejach i tradycji, red. J. Gmitruk, A. Stawarz, Warszawa 2004, s. 43.

${ }^{2}$ M. FranČIĆ, Insurekcja Kościuszkowska, Kraków 1988, s. 32.

${ }^{3}$ T. RAwSKI, Wojsko Rzeczypospolitej Obojga Narodów wobec groźby unicestwienia państwa (1793-1794), w: Insurekcja Kościuszkowska w dziejach i tradycji, s. 22.

${ }^{4}$ M. SICIŃsKI, Wojsko powstania kościuszkowskiego, jego uzbrojenie i ubiór, w: Powstanie Kościuszkowskie i jego naczelnik, red. M. Ochman, M. Skotnicki, Warszawa 2017, s. 20.

${ }^{5}$ W. ŁukASZEwICZ, Targowica i powstanie Kościuszkowskie, Warszawa 1953, s. 218.

${ }^{6}$ M. FRANČIĆ, Insurekcja, s. 66-67.
} 
W maju do walki z powstańcami przyłączyła się armia pruska, która próbowała zdusić ruchy narodowościowe na kontrolowanym przez siebie terenie. 6 czerwca Kościuszko poniósł klęskę pod Szczekocinami, a dwa dni później generał J. Zajączek został pobity pod Chełmem. Wojska powstańcze zostały zmuszone do wycofania się ku Warszawie. W połowie czerwca Prusacy bez walki zajęli Kraków, niemniej bitwa stoczona w początkach lipca pod Warszawą powstrzymała nieprzyjaciela i pozwoliła zakończyć przygotowania do obrony miasta, którego oblężenie trwało od 22 lipca do 5 września ${ }^{7}$. Kolejne działania miały miejsce $\mathrm{w}$ Wielkopolsce, gdzie powstanie wybuchło 20 sierpnia i odznaczyło się sporymi sukcesami, które skłoniły wojska pruskie do wycofania się spod Warszawy. Na pomoc powstańcom wielkopolskim Kościuszko wysłał korpus pod dowództwem Jana Henryka Dąbrowskiego, który na początku października zdobył Bydgoszcz i wkroczył na Pomorze. Niestety także powstanie na Litwie zostało stłumione, a nowa armia rosyjska, pod dowództwem Aleksandra Suworowa, odniosła zwycięstwo pod Krupczycami i Terespolem ${ }^{8}$. Aby nie dopuścić do połączenia się wszystkich wojsk rosyjskich, Kościuszko wydał Iwanowi Fersenowi bitwę pod Maciejowicami, która zakończyła się klęską Polaków, a ranny Kościuszko dostał się do niewoli. Nowym naczelnikiem powstania został Tomasz Wawrzecki, a faktyczne dowództwo wojska objął generał Józef Zajączek. Suworow, połączywszy się z wojskiem Fersena, ruszył na Warszawę, 4 września zdobył szturmem Pragę, dokonując rzezi ludności, Warszawa skapitulowała 5 listopada. Wawrzecki z częścią wojska wycofał się na południe, a 16 listopada pod Radoszycami nastąpiło ostateczne rozwiązanie oddziałów ${ }^{9}$. Po upadku powstania Austria, Prusy i Rosja dokonały III rozbioru Polski w 1795 r.

Powstanie kościuszkowskie miało ogromny wpływ na rozwój polskiej myśli politycznej. Próby Kościuszki wciągnięcia do walki mas ludowych i mieszczan zaowocowały ruchami wolnościowymi, łączącymi walkę o niepodległość z programem reform społecznych. Ta świadomość trwała w narodzie, który często odwoływał się do tradycji kościuszkowskich, starając się nie zatracić tego ducha walki.

\footnotetext{
${ }^{7}$ A. ŚLIwiŃSKI, Powstanie Kościuszkowskie, Warszawa 2014, s. 148-160.

${ }^{8}$ M. FrANČIĆ, Insurekcja, Kraków 1988, s. 99.

${ }^{9}$ Tamże, s. 115.
} 


\section{HISTORIA ODDZIAŁU}

Bieździedza ${ }^{10}$ cieszy się bogatą historią i licznymi zabytkami kultury, zarówno materialnymi w postaci gotyckiego kościoła ${ }^{11}$ czy klasycystycznego dworu ${ }^{12}$, jak i niematerialnymi - reprezentowanymi przez mieszkańców podtrzymujących wielowiekowe tradycje, do których można zaliczyć Kosynierów im. Tadeusza Kościuszki.

$\mathrm{Na}$ zarysowanym w pierwszej części tle historycznym widać fenomen bieździedzkiego oddziału Kosynierów, który nawiązuje do chłopów uzbrojonych w kosy biorących udział w powstaniu. Należy jednak dodać, iż w lokalnych galicyjskich warunkach przełomu XIX i XX w. dokonuje się transformacja świadomości narodowej wśród warstwy chłopskiej. Pojawiające się ówcześnie prądy intelektualne Młodej Polski, m.in. chłopomania, sprzyjają tworzeniu grup odwołujących się w swej działalności do historycznych zwycięstw Polaków czy wydarzeń pokrzepiających ducha narodu. $Z$ tym zjawiskiem łączy się ściśle praca społeczna (w tym patriotyczna) księży wśród parafian, do czego szczególnie zachęcał duchowieństwo łacińskiej diecezji przemyskiej bp Józef Sebastian Pelczar (Bieździedza należała do tegoż biskupstwa w latach 1805-1992) ${ }^{13}$.

Biorąc pod uwagę wskazane zależności, można mówić o zasadności powstania tytułowego oddziału. Trzeba także zauważyć, że nie istnieje kronika, czy jakiekolwiek dokumenty wprost dotyczące omawianego zagadnienia. Większość wiadomości jest przekazywana przez pokolenia, a ci mieszkańcy Bieździedzy i Bieździadki, którzy zostają włączeni do oddziału, są głównym źródłem informacji.

\footnotetext{
${ }^{10}$ Wieś położona w województwie podkarpackim, wzmiankowana w dokumencie benedyktynów z Tyńca datowanym na lata 1123-1125. W. KĘTRZYŃSKI, Kodeks dyplomatyczny klasztoru tynieckiego, cz. I, Lwów 1875, s. 2.

${ }^{11}$ W latach 1402-1409 wzniesiono kamienny kościół, którego budowę sfinansowali Helwigowie. W kwietniu 1436 r. biskup Zbigniew Oleśnicki erygował samodzielną prebendę przy kościele w Bieździedzy, natomiast konsekracja kościoła miała miejsce 7 stycznia 1453 r. Dokonał jej biskup Jerzy, sufragan kardynała Zbigniewa Oleśnickiego. Kościół poświęcono Trójcy Świętej. W ciągu dziejów wygląd świątyni przechodził liczne zmiany, niemniej gotycki charakter świątyni pozostał do dziś. APB, Kronika Parafii Bieździedza, t. 1, s. 2.

${ }^{12}$ Wzniesiony w XVII wieku przez właścicieli Bieździedzy - Romerów. Jego przebudowę w stylu klasycystycznym przeprowadzili w I połowie XIX stulecia kolejni dziedzice wsi - Bobrowscy, a kilkadziesiąt lat później spokrewnieni z nimi Zborowscy. A. KozIOŁ-LECHOwski, Parafia Bieździedza w ciagu dziejów, Rzeszów 1997, s. 98.

${ }^{13}$ T. KARGOL, Świadomość chłopów w Galicji w pierwszej połowie XIX wieku. Zarys problemu. w: ,Zeszyty Naukowe Uniwersytetu Jagiellońskiego. Prace Historyczne, 144” 2017, z. 2, s. 406
} 
Ubogie źródła pisane nie pozwalają na podanie daty powołania do istnienia oddziału. W nielicznych opracowaniach znajduje się czas powstania określany pomiędzy 1810 r. a 1815 r. ${ }^{14}$ Bolesław Wójtowicz w swojej dysertacji poświęconej Bieździedzy wskazuje na blisko 400-letnią tradycję istnienia oddziału, który wywodzi się od Straży Grobowej działającej przy parafii, a pełniącej swe funkcje głównie w czasie Świąt Wielkanocnych ${ }^{15}$. Bieździedzki oddział miał mieć pochodzenie i tradycje militarne wywodzące się także z czasów Stefana Batorego, Jana III Sobieskiego i ich zwycięskich bitew. Za istnieniem takiego oddziału w Bieździedzy może przemawiać sztandar z 1904 r. Na szarfie czytamy bowiem „Gwardia Kozaków Stefana Batorego pod opieką NMP - Wiara i Ojczyzna”. Sztandar został ufundowany w 1904 r. przez Polonię amerykańską właśnie dla Gwardii Kozaków, a nie dla istniejącego już wtedy oddziału Kosynierów. Kosynierzy bowiem podjęli swoją działalność w 1893 r., o czym będący na obczyźnie mogli nie wiedzieć. Informacje na temat istniejącego już wtedy oddziału Kosynierów znajdują się w Kronice Parafii Bieździedza, lecz mówią one o ich obecności związanej z wizytacją biskupią ${ }^{16}$. Niemniej należy przyjąć blisko 125-letnie istnienie grupy, która została powołana dla podtrzymywania tradycji insurekcji kościuszkowskiej; oręża króla Jana III Sobieskiego - tzw. Wiktorii Wiedeńskiej i oręża króla Stefana Batorego. Zadania i funkcje, pełnione przez Kosynierów, nie uległy zmianie w porównaniu do zadań Gwardii Kozaków, o umundurowaniu i uzbrojeniu z pierwszych lat funkcjonowania nie ma bliższych informacji, natomiast współczesne zostaną omówione w dalszej części.

Wracając do 1893 r. należy wspomnieć, iż ówczesny proboszcz parafii Bieździedza ks. Stanisław Boczar ${ }^{17}$ wraz z kolatorem wsi hr. Stefanem Romerem $^{18}$, Michałem Wójcikiem ${ }^{19}$ i Janem Mazurem podjęli decyzję o reaktywacji i odnowieniu oddziału Kozaków, który mocno podupadł i zaniechał działalności. Nowa formacja miała tak naprawdę zastąpić Gwardię Kozaków Stefana Batorego przy jednoczesnym zachowaniu jej funkcji. Ponadto postanowiono również upamiętnić 19 kosynierów z Bieździedzy, którzy mieli brać udział w bitwie pod

\footnotetext{
${ }^{14}$ Cz. Leosz, Bieździedza. Wieś-Szkoła-Kosynierzy-Ochotnicza Straż Pożarna-100-lecie, Bieździedza 2005, s. 99.

${ }^{15}$ B. Wóstowicz, Przewodnik turystyczny, Bieździedza 2011, s. 85.

${ }^{16} \mathrm{APB}, K P B$, t. 1 , s. 12.

${ }^{17}$ Ks. Stanisław Boczar - proboszcz Bieździedzy od 1887 r. Zmarł w 1905 r.

${ }^{18}$ Stefan hr. Zborowski ze Zborowa h. Jastrzębiec, ur.1863 r., zm. 1922 r. - Kolator bieździedzki.

${ }^{19}$ Michał Wójcik - mieszkaniec Bieździadki, ur. w 1863 r., zm. 1940 r. - pierwszy dowódca oddziału od 1893 r.
} 
Racławicami 4 kwietnia 1794 r. pod wodzą Tadeusza Kościuszki. Z tej okazji wokół placu kościelnego zasadzono 19 lip $^{20}$.

Oddział, po odnowieniu, złożony był z 24 młodych chłopów, którzy zostali umundurowani na wzór powstańców z okolic Krakowa (białe sukmany, buty z cholewami, czerwona czapka rogatywka i kosa $)^{21}$. Dowództwo w oddziale objął Michał Wójcik, chorążym został Jan Mazur. Kosynierzy po raz pierwszy zaprezentowali się w czasie Świąt Wielkanocnych w 1893 r. Od tego czasu pod nadzorem komendanta ćwiczyli musztrę paradną i prezentowali się witając przybyłych do parafii gości ${ }^{22}$. W 1904 r. oddział otrzymał sztandar, o którym już wspomniano. W czasie pogrzebu ks. Boczara w 1905 r. Kosynierzy pełnili szczególną wartę przy jego trumnie, dziękując za inicjatywę odnowienia. Kolejny proboszcz bieździedzki - ks. Ignacy Łonicki ${ }^{23}$ - zobowiązał się wspierać Kosynierów i ich działania. W czasie I wojny światowej jedynie w 1915 r. zaniechano pełnienia służby przy Grobie Pańskim przez Kosynierów w obawie przed żołnierzami rosyjskimi. Mundury i sztandar zostały ukryte na ten niespokojny czas. W 1918 r. ma miejsce zmiana na stanowisku komendanta. Funkcję tę przejmuje Stanisław Kozioł, który jako wojskowy wprowadza większą dyscyplinę wśród Kosynierów. Rolę chorążego zaczyna pełnić Józef Urban. Inne obowiązki, jakie spoczywały na barkach Kozioła, doprowadziły go do rezygnacji z przewodzenia Kosynierom w 1920 r. Komendantem został dotychczasowy chorąży, który na swoje miejsce mianował Tadeusza Urbana. Ze względu na znakomite przygotowanie wojskowe i duży szacunek, jakim cieszył się Stanisław Kozioł, oddział powierzył mu funkcję zwierzchnią określając majorem. Tego rodzaju wyróżnienie dla byłego komendanta utrzymuje się do dnia dzisiejszego.

W 1930 r. pojawia się szereg zmian w życiu społeczno-politycznym wsi. Powstają nowe organizacje, co sprawia, że niektórzy mieszkańcy stają się członkami kilku grup jednocześnie. W tych okolicznościach komendant i chorąży podejmują decyzję o rezygnacji i oddaniu szabli komendanta Janowi Młodeckiemu, który przewodzi również Oddziałowi Strzelca. Dzieje się to za aprobatą hr. Wilhelma Romera - kolatora wsi. Na chorążego zostaje powołany Piotr Urban. Normalna działalność oddziału trwa do 1939 r., wtedy to, tuż przed wybuchem wojny, w sierpniu, na uroczystość Wniebowzięcia Najświętszej Maryi Panny

\footnotetext{
${ }^{20}$ Do dziś przy kościele rośnie jeszcze siedem z nich.

${ }^{21} \mathrm{APB}, K P B$, t. 1 , s. 12.

${ }^{22}$ Jeszcze w czerwcu 1893 r. oddział uroczyście przywitał przybyłego na wizytację ks. bpa Jakuba Glazera - sufragana przemyskiego, o czym przypomina Kronika parafialna. APB, $K P B$, t. 1, s. 12.

${ }^{23}$ Ks. Ignacy Łonicki - proboszcz Bieździedzy od 1905 r. Zmarł w 1927 r.
} 
mundury Kosynierów zostały wypożyczone młodym chłopcom z Gorajowskich Gór, którzy swoją obecnością mieli uświetnić uroczystości odpustowe w jasielskiej Farze. Niestety wraz z wybuchem wojny całe umundurowanie przepadło, co mocno ograniczyło funkcjonowanie Kosynierów, zawieszone zresztą na czas wojny. Po ustabilizowaniu się sytuacji i powrocie z wysiedlenia w 1945 r. oddział zostaje odnowiony ${ }^{24}$. Funkcję komendanta przejmuje Piotr Urban, a chorążego Stanisław Lechwar. Zorganizowano nowe mundury, wykonano nową broń, niezwykła historia wiąże się ze sztandarem, co zostanie przedstawione w kolejnym punkcie. Wielkanoc w 1945 r. przeżywana jest już z udziałem Kosynierów. W 1950 r. mają miejsce kolejne zmiany w dowództwie. Komendantem zostaje Andrzej Grzebieniowski, a chorążym Józef Kozioł. Za zasługi po wojnie i odnowienie oddziału majorem zostaje mianowany Piotr Urban, który z pieczołowitością doglądał działalności oddziału. W 1962 r. Grzebieniowski oddaje dowództwo Józefowi Koziołowi, który na chorążego wybiera Stefana Skocza. W 1974 r. po ustąpieniu Kozioła przywództwo w oddziale przejmuje dotychczasowy chorąży, mianując na swoje miejsce Józefa Liszkę. Nagła śmierć Liszki w 1982 r. powoduje, iż funkcje chorążego przekazane zostały Stanisławowi Mamrołowi. Stefan Skocz był komendantem przez 33 lata. W 2007 r. szablę przejmuje Bogdan Lechwar, przy zachowaniu dotychczasowego chorążego. Śmierć Mamroła w 2010 r. sprawia, iż chorążym zostaje Wiesław Kowalski, pełniąc tę funkcję do dnia dzisiejszego. W 2017 r. Lechwar przekazuje szablę komendanta Bartłomiejowi Ochałkowi. Liczba kosynierów w czasie funkcjonowania oddziału często się zmieniała, wahając od 15 do 25 osób.

Kosynierzy w swojej powojennej historii odnotowują jeszcze jedno istotne wydarzenie, które miało miejsce 11 listopada 2002 r. Było to uroczyste przekazanie nowego sztandaru, o który postarał się Urząd Gminy Kołaczyce, korzystając ze środków fundacji „Karpaty-Polska” na rzecz projektu „Ochrona i promocja folkloru, obrzędów ludowych kultywowanych w gminie Kołaczyce”. W tym czasie wykonano nowe mundury i uzbrojenie dla oddziału Kosynierów. Do tych działań przyczyniła się Teresa Drzymalska, pełniąca ówcześnie funkcję Inspektora do spraw kultury w gminie Kołaczyce ${ }^{25}$.

\footnotetext{
${ }^{24}$ Wysiedlenie Bieździedzy zostało zapowiedziane i zrealizowane 20 września 1944 r., co miało związek z przesunięciem się linii frontu. A. KozıoŁ-Lechowski, Parafia Bieździedza, s. 79.

${ }^{25}$ B. Wójtowicz, Przewodnik turystyczny, s. 94.
} 


\section{UMUNDUROWANIE I WYPOSAŻENIE}

Odział bieździedzkich Kosynierów posiada bardzo charakterystyczne umundurowanie nawiązujące swym wyglądem do tego, jakie w czasie powstania kościuszkowskiego mieli na sobie walczący chłopi. Ubiór był kilkukrotnie odnawiany ze względu na burzliwe dzieje oddziału. Obecnie mundur składa się z białej koszuli, na którą zakłada się czarną kamizelkę ze stójką (na stójce wyszyty jest stopień wojskowy). Kamizelka jest przepasana dość szerokim, skórzanym pasem, na którego sprzączce jest wybita podobizna Tadeusza Kościuszki. Spodnie to tzw. pasiaki, białe w czerwone, pionowe paski, które należy wpuścić do cholew butów. Każdy z Kosynierów posiada czarne, skórzane buty z cholewą, tzw. oficerki. Całość dopełnia biała, lniana sukmana ze stójką zwana płócienką lub płótnionką. Sukmana nie posiada guzików, ani nie przepasuje się jej pasem. Na głowie każdego Kosyniera znajduje się czapka rogatywka krakowska z pawim, indyczym lub bażancim piórem. Ma ona formę konfederatki z czarnym, futrzanym otokiem i sukiennym wierzchem. Czapka nie posiada daszka, ma główkę z kwadratowym denkiem w kolorze karmazynowym. Na denku przyszyta jest złota nitka, która krzyżuje się na środku. Czapka jest zapinana na brodzie skórzanym paskiem. Każdy kosynier uzbrojony jest w kosę postawioną na sztorc. Drzewiec (kosisko) nie posiada rączki na środku ${ }^{26}$.

Strój komendanta i chorążego nieco różni się od pozostałych. Komendant na swojej czapce, tuż nad czarnym futrem, posiada dwa złote równolegle biegnące pasy. Jego kamizelka jest czerwona, a zamiast kosy wyposażony jest w szablę ułańską ozdobioną warkoczem wyplecionym z kremowego sznura zakończonym czerwono-kremowym pomponem. Chorąży, podobnie jak komendant, posiada czerwoną kamizelkę i szablę ułańską zamiast kosy. Dodatkowo, jako jedyny z oddziału, przepasany jest szarfą, która jest dwustronna. Czerwona z jednej strony, a czarna z drugiej, do szarfy przypinany jest krzyż. Zadaniem chorążego jest trzymanie sztandaru oraz rozprowadzanie kosynierów podczas zmiany warty przy Grobie Pańskim ${ }^{27}$.

Bardzo ważnym elementem, stanowiącym o tożsamości oddziału, jest sztandar. Bieździedzcy kosynierzy posiadają dwa tego rodzaju weksylia, z czego jeden z nich jest sztandarem historycznym, dziś już nie używanym, aczkolwiek historia, jaką przeszedł, jest niezwykle burzliwa. Nie wiadomo, czy oddział zaraz po powstaniu posiadał sztandar. Najprawdopodobniej było to zbyt kosztowne jak na

\footnotetext{
${ }^{26}$ E. PIEKARSKA, Tradycyjne rękodzieło ziemi kołaczyckiej, Kołaczyce 2014, s. 41.

${ }^{27}$ Cz. LeOsz, Bieździedza. Wieś-Szkoła, s. 101.
} 
tak niewielką miejscowość. Przed 1893 r., jak już to było wspominane, w bieździedzkiej parafii istniała Gwardia Kozaków Stefana Batorego, która pełniła funkcje reprezentatywne na uroczystościach kościelnych oraz państwowych i Gwardia ta również nie posiadała sztandaru. Wiedziało o tym fakcie wielu mieszkańców, którzy pod koniec XIX zaczęli opuszczać Bieździedzę i wyjeżdżać w różne strony. Zapewne po kilku latach pracy na obczyźnie przypomnieli sobie o rodzinnej miejscowości i potrzebach tych, którzy w niej pozostali. Takim to najprawdopodobniej sposobem w 1904 r. do Bieździedzy trafił sztandar ufundowany przez Polonię Amerykańską. Będąc poza granicami Polski nie wiedzieli oni, iż Gwardia Kozaków Polskich została zastąpiona oddziałem Kosynierów, stąd napis na szarfie sztandaru brzmiał: „Gwardia Kozaków Polskich Stefana Batorego pod opieką NMP - Wiara i Ojczyzna, październik 1904 r. Carnegie Pensylwania USA". Sztandar ma barwy narodowe - biel i czerwień - obszyte złotymi frędzlami. Na awersie widnieje orzeł w koronie przedstawiony w prostym kartuszu herbowym, rewers zawiera wyszywany obraz Matki Bożej Częstochowskiej. Drzewiec ozdobiony srebrnymi gwoźdźmi z nazwiskami późniejszych darczyńców wieńczy srebrna kula z orłem, do drzewca przymocowana jest białoczerwona szarfa.

Opisany powyżej sztandar ma swoją historię związaną z wojennymi zawieruchami. O ile lata 1914-1918 nie wiązały się ze znaczniejszymi zmianami na terenach parafii Bieździedza, gdyż jedynie w roku 1915 kosynierzy nie podejmowali swojej działalności w obawie przed obcymi władzami, o tyle lata II wojny światowej wyglądały zupełnie inaczej. Na czas wojny funkcjonowanie oddziału było zawieszone, a wszelkie elementy związane z patriotyczną działalnością ukrywane. Zapowiedziane na 20 września 1944 r. wysiedlenie Bieździedzy sprawiło, iż ówczesny proboszcz ks. Stanisław Bałuk ${ }^{28}$ i kilku zaufanych mu ludzi podejmują decyzję o ukryciu monstrancji, kielichów, ornatów, sztandaru

\footnotetext{
${ }^{28}$ Ks. Stanisław Bałuk - ur. 18 sierpnia 1887 w Podgórzu (Kraków), zm. 3 lipca 1975 w Bieździedzy. W latach 1897-1905 uczęszczał do gimnazjum najpierw w Podgórzu, następnie w Rzeszowie. W latach 1905-1908 studiował na Wydziale Prawa Uniwersytetu Jagiellońskiego w Krakowie. Po uzyskaniu tytułu magistra prawa rozpoczął studia teologiczne w Wyższym Seminarium Duchownym w Przemyślu. Otrzymał święcenia kapłańskie 29 czerwca 1913 roku. W okresie okupacji hitlerowskiej wspierał swoich parafian. W trakcie wysiedlenia w 1944 roku przebywał na plebanii w Bączalu Dolnym, gdzie dał mu schronienie ówczesny proboszcz bączalski ks. Florian Zając zaangażowany w walkę z okupantem. Jako absolwent prawa pomagał w sprawach sądowych oraz w kontaktach z miejscowymi władzami. Znał język niemiecki, stąd też w okresie okupacji był wykorzystywany jako tłumacz. Proboszcz bieździedzki od 1927 r. do 1975 r. Pochowany na cmentarzu w Bieździedzy. A. KozıoŁLeCHOwsKi, Parafia Bieździedza, 68-72.
} 
Kosynierów i kilku cenniejszych rzeczy przed Niemcami. Postanowiono wymienione wyżej przedmioty włożyć do przygotowanej wcześniej trumny i pod pozorem pośpiesznego pogrzebu w obecności kilku osób „pochować”. Niemieccy żołnierze mieli zwyczaj kontrolować trumny i sprawdzać czy niczego cennego nie ukrywa się wraz ze zmarłym. Aby tak się nie stało została im przekazana wiadomość, iż „zmarły”, który miał zostać pochowany, był chory na tyfus, a tej choroby Niemcy obawiali się bardzo. W pośpiesznym ,pogrzebie”, obok ks. Bałuka wzięli udział: Józef Sypień - ówczesny kościelny, jego syn Jan, grabarz Jan Mamroł i chorąży Piotr Urban. Istnieją dwie relacje na temat miejsca, gdzie ukryto te kosztowności. Pierwszym miał być grób ks. Stanisława Boczara ${ }^{29}$ i to tam dziś znajduje się niewielka tabliczka informująca o tych wydarzeniach ${ }^{30}$. Jednak bardziej prawdopodobne jest drugie miejsce - grobowiec ks. Ignacego Łonickiego, gdyż grób ks. Boczara znajduje się w ziemi i wymagałby dodatkowych czynności, które przygotowałyby miejsce pod dodatkową trumnę, natomiast w dość dużym grobowcu ks. Łonickiego łatwiej i szybciej można było przeprowadzić całą operację $e^{31}$. Niemniej o tych wydarzeniach wiedzieli jedynie obecni, a najmłodszy z nich Jan Sypień miał przekazać tę opowieść dalszym pokoleniom. Po powrocie $\mathrm{z}$ wysiedlenia $\mathrm{w}$ styczniu $1945 \mathrm{r}^{32}$, po ustabilizowaniu się sytuacji, wydobyto trumnę z kosztownościami i przywrócono je na właściwe miejsce. Jednak nie można ustalić kiedy dokładnie się to stało. Ważne natomiast, iż sztandar przetrwał wojenną zawieruchę i przez kolejne lata mógł służyć Kosynierom.

W 2002 r., o czym też już była mowa, Kosynierzy otrzymali nowy proporzec i umundurowanie, które pozostało w niezmienionej formie i kolorystyce, nowy sztandar nawiązuje barwami i symbolami do poprzedniego. Wykonany z białoczerwonego materiału na awersie posiada godło narodowe oraz napis „Żywią i Bronią 1904-2002,33, na rewersie widnieje wizerunek Matki Bożej Częstochowskiej i napis „Oddział Kosynierów z Bieździedzy”. Szczyt drzewca zdobi srebrny orzeł. Sztandar ten uroczyście poświęcono i przekazano oddziałowi 11 listopada 2002 r. w czasie Mszy świętej sprawowanej za Ojczyznę w kościele parafialnym w Bieździedzy.

\footnotetext{
${ }^{29}$ Ks. Stanisław Boczar - proboszcz Bieździedzy od 1887 r. Zmarł w 1905 r. Tamże, s. 61.

${ }^{30}$ Tę wersję podaje B. Wójtowicz, Przewodnik turystyczny, s. 92.

${ }^{31}$ Relacja ta nie posiada udokumentowania, przekazywana jest ustnie przez najstarszych Kosynierów razem z historią sztandaru.

${ }^{32}$ A. KozioŁ-Lechowski, Parafia Bieździedza, s. 80.

${ }^{33}$ Żywią i Bronią (oryg. żywią y bronią) - dewiza kosynierów z czasów Insurekcji Kościuszkowskiej. Hasło odnosi się do roli społecznej chłopów, którzy w czasie pokoju ciężką pracą na roli zaopatrują społeczeństwo w żywność niezbędną do przetrwania, a w czasie wojny bronią je przed zewnętrznym wrogiem.
} 


\section{TRADYCJE}

Działalność omawianej grupy od samego początku wiązała się z funkcją reprezentatywną. Kosynierzy nigdy nie angażowali się militarnie w jakiekolwiek konflikty. Jak to już było powiedziane, mieli podtrzymywać pamięć i tradycje związane z insurekcją kościuszkowską, stąd ich udział we wszelkich uroczystościach patriotyczno-narodowych, które organizowane są na szczeblu gminy, powiatu bądź województwa. Ponadto, nawiązując do tradycji formacji, którą niejako zastąpili (Gwardii Kozaków Polskich Stefana Batorego), kontynuują zwyczaj Straży Grobowej w czasie Świąt Wielkanocnych, co wiąże się z pewnego rodzaju obrzędem.

Od momentu zakończenia Liturgii Wielkiego Piątku, Kosynierzy obejmują straż przy Grobie Chrystusa, warta dwóch z nich trwa 30 minut, a kolejne zmiany rozprowadza chorąży, który jako pierwszy wkracza do świątyni trzymając w dłoni szablę. W Wielką Sobotę przed bieździedzkim kościołem słychać rozkazy: „Baczność! Na ramię broń! Prezentuj broń! Na lewo patrz!”, a trębacz w tym czasie gra hejnał kosynierski. Salutujący oddział w ten sposób oddaje honory mieszkańcom miejscowości. Straż przy Grobie trzymana jest do Rezurekcji, kiedy to cały oddział bierze udział w uroczystej procesji. W poniedziałek wielkanocny na wspólnym zebraniu Kosynierów nadawane są kolejne stopnie honorowe za nienaganną służbę, zaangażowanie na rzecz parafii i wsi, co jest nawiązaniem do tradycji wojskowych. Wspomniane stopnie są przyznawane przez komendanta w porozumieniu z majorem i wiążą się z odpowiednimi oznaczeniami na stójce kamizelki. I odpowiednio młodszy kosynier nie posiada żadnego oznaczenia, starszy kosynier - jeden biały pasek na stójce, kapral - dwa paski, plutonowy trzy, sierżant - krokiewkę zwróconą do zapięcia węższym końcem, starszy sierżant - dwie krokiewki ${ }^{34}$.

Kosynierzy biorą udział również w uroczystościach związanych z odpustami parafialnymi, Uroczystością Najświętszego Ciała i Krwi Pańskiej oraz dożynkami. To dożynki właśnie są tym okresem, kiedy oddział może się zaprezentować również poza swoją miejscowością, uczestnicząc w dożynkach gminnych, powiatowych czy diecezjalnych. Ważnym aspektem ich działalności jest również coroczna Ogólnopolska Parada Straży Grobowych „Turki”, która dla oddziału Kosynierów stała się już tradycją ${ }^{35}$.

\footnotetext{
${ }^{34}$ Cz. LeOSZ, Bieździedza Wieś-Szkoła, s. 102.

${ }^{35} \mathrm{~W}$ określonym przez organizatora miejscu zjeżdżają się formacje, które pełnią wartę przy Grobie Pańskim. Parada odbywa się przeważnie w drugą niedzielę po Świętach Wielkanocnych. Ostatnia odbyła się w Majdanie Zbydniowskim 15 kwietnia 2018 r.
} 
Podsumowując należy zaznaczyć, iż omawiany oddział Kosynierów z Bieździedzy jest ewenementem na Podkarpaciu ze względu na swoją wielowiekową historię i podtrzymywane tradycje. Warto dbać, aby nie zabrakło kontynuatorów tego dzieła.

\section{BIBLIOGRAFIA}

I. ŹRÓDłA

Archiwum Parafii Bieździedza, Kronika Parafii Bieździedza, t. 1-2.

KĘTRZYŃSKI W., Kodeks dyplomatyczny klasztoru tynieckiego, cz. I, Lwów 1875.

\section{LITERATURA}

FRANČIĆ M., Insurekcja Kościuszkowska, Kraków 1988.

GMitruK J, MAZureK J., Tradycja racławicka w ruchu ludowym w: Insurekcja Kościuszkowska w dziejach i tradycji, red. J. Gmitruk, A. Stawarz, Warszawa 2004, s. 81-100.

KARGol T., Świadomość chtopów w Galicji w pierwszej połowie XIX wieku. Zarys problemu. „Zeszyty Naukowe Uniwersytetu Jagiellońskiego Prace Historyczne, 144” 2017, z. 2, s. 401-411.

KozIOŁ-Lechowski A., Parafia Bieździedza w ciagu dziejów, Rzeszów 1997.

Leosz Cz., Bieździedza. Wieś-Szkoła-Kosynierzy-Ochotnicza Straż Pożarna-100-lecie, Bieździedza 2005.

ŁUKASZEWICZ W., Targowica i powstanie Kościuszkowskie, Warszawa 1953.

PIEKARSKa E., Tradycyjne rękodzieło ziemi kołaczyckiej, Kołaczyce 2014.

RAwsKi T., Wojsko Rzeczypospolitej Obojga Narodów wobec groźby unicestwienia państwa (17931794), w: Insurekcja Kościuszkowska w dziejach i tradycji, red. J. Gmitruk, A. Stawarz, Warszawa 2004, s. 9-23.

SicıŃSKi M., Wojsko powstania kościuszkowskiego, jego uzbrojenie i ubiór, w: Powstanie Kościuszkowskie i jego naczelnik, red. M. Ochman, M. Skotnicki, Warszawa 2017, s. 13-35.

ŚLIwIŃski A., Powstanie Kościuszkowskie, Warszawa 2014.

Wóstowicz B., Przewodnik turystyczny, Bieździedza 2011.

Wysocki W.J., Władze powstańcze w 1974 r., w: Insurekcja Kościuszkowska w dziejach i tradycji, red. J. Gmitruk, A. Stawarz, Warszawa 2004, s. 43-50.

ZAJEWSKI W., Bitwy o Wilno w Insurekcji Kościuszkowskiej w: Insurekcja Kościuszkowska w dziejach i tradycji, red. J. Gmitruk, A. Stawarz, Warszawa 2004, s. 63-70.

\section{ODDZIAŁ KOSYNIERÓW Z BIEŹDZIEDZY - POWSTANIE I DZIAŁALNOŚĆ}

$$
\text { Streszczenie }
$$

Powstanie kościuszkowskie z 1794 r. było niezwykle ważnym wydarzeniem w historii Polski. Pamięć o nim, jak i o samym Tadeuszu Kościuszce wlewała w serca Polaków nadzieję na odzyskanie niepodległości. Wzrost świadomości narodowej wśród warstwy chłopskiej w Galicji, połączony 
z pracą społeczną (w tym także patriotyczną) księży pośród nich, owocował tworzeniem wielu formacji mających na celu podtrzymywanie ducha patriotyzmu.

Oddział Kosynierów w Bieździedzy doskonale wpisuje się w ten nurt łączący w sobie idee Młodej Polski z zachętami płynącymi m.in. od bpa Józefa Sebastiana Pelczara. Wiele trudności sprawia dokładne zrekonstruowanie dziejów omawianego oddziału, czego przyczyną są nieliczne źródła pisane. Nieoceniona w takim przypadku pozostaje pamięć ludzi jak i przekazywana tradycja.

Niniejszy artykuł przybliża historię powstania bieździedzkiego oddziału Kosynierów i jego losy; omawia umundurowanie i uzbrojenie oraz zaznacza, jaką dziś pełnią funkcję ci, którzy do niego należą.

Słowa kluczowe: Bieździedza; Kosynierzy; powstanie kościuszkowskie; oddział. 